DOI: 10.34015/2523-4552.2020.1.04

УДК: 342.518

\begin{abstract}
Ярмиш О. Н., доктор юридичних наук, професор, член-кореспондент Національної академії правових наук України, заслужений юрист України, головний науковий співробітник Інституту законодавства Верховної Ради України ORCID: 0000-0002-4811-4520
\end{abstract}

\title{
ПЕРЕТВОРЕННЯ У ПРАВООХОРОННІЙ СИСТЕМІ НЕЗАЛЕЖНОЇ УКРАЇНИ: ЧОМУ ВОНИ ДОТЕПЕР НЕ ПРИНЕСЛИ УСПІХІВ? (РОЗДУМИ ВЕТЕРАНА-УЧАСНИКА РЕФОРМАЦІЙНИХ ПОТУГ)
}

У статті з позицій наукової обгрунтованості та практичного досвіду розглянуто реформи правоохоронної системи, оцінено здобутки й вади на шляху реформування органів поліції, прокуратури, СБУ, кримінально-виконавчої служби упродовж останніх років. Пропонується розглядати зазначені об'єкти реформування не ізольовано, а в якості складових інституційної системи, 3 огляду на ефективність перетворень усієї державно-правової структури. Тому не можна зупинятися на реформах в межах однієї інституції.

Ключові слова: правоохоронні органи; правоохоронна система; поліція; реформа; інтегральна модель реформи.

В статье с позиций научной обоснованности и практического опыта рассмотрены реформы правоохранительной системы последних лет, оценены достижения и недостатки на пути реформирования органов полиции, прокуратуры, СБУ, уголовно-исполнительной службы и др. Автор предлагает рассматривать указанные объекты реформирования не изолированно, а в качестве составляющих институциональной системы с точки зрения эффективности преобразований всей государственно-правовой структуры. Поэтому нельзя останавливаться в пределах реформирования одного учреждения.

Ключевые слова: правоохранительные органы; правоохранительная система; полиция; реформа; интегральная модель реформы.

Постановка проблеми. Коли редакція «Вісника Пенітенціарної асоціації України» запропонувала мені підготувати статтю щодо проблем реформування правоохоронних органів, i кримінально-виконавчої системи зокрема, я погодився, поставивши лише одну умову, - щоб мій допис не належав до традиційного жанру наукової журнальної статті (3 класичною структурою, посиланнями на використані джерела тощо), а мав вигляд «вільних» роздумів активного учасника реформаційних процесів з тридцятирічним стажем. Бо за цей час я написав чимало статей, 
доповідних записок, проектів, тез, але без вагомого практичного результату. Тож доповнювати цей чималенький масив ще однією повноформатною статтею з черговою низкою пропозицій вже не хотілося навіщо? Нікому, крім деяких колегнауковців, ці пропозиції не цікаві.

Виклад основного матеріалу. Водночас, $є$ сенс зупинитись, озирнутися назад, спокійно проаналізувати й оцінити перебіг і результати масштабних, загальних і локальних спроб реформувати правоохоронну систему, що дісталася нам у спадок від радянської доби. Вважаю, що маю моральне право на такий аналіз, оскільки зробив перші кроки на реформаторській ниві у згаданій сфері ще в далекому 1990 році, коли як доцент Юридичного інституту у Харкові, фахівець 3 історії поліції, був залучений до розробки проекту Закону УРСР «Про міліцію». До речі, дуже непоганий закон вийшов: прогресивний, новаторський (був першим нормативно-правовим актом такого роду серед законів союзних республік), органічно вписався в законодавство незалежної України, був напрочуд стабільним - 3 незначною кількістю змін зберігав чинність аж до 2015 року , коли міліція поступилася місцем в державному механізмі поліції. Далі була напружена й водночас захоплююча багаторічна робота зі створення та розбудови національної системи підготовки кадрів для органів внутрішніх справ України (на початок 90-х років таку багаторівневу систему в повному обсязі мала лише Російська Федерація). Справжню школу законотворчості у правоохоронній сфері ми, науковці Університету внутрішніх справ, пройшли під керівництвом ректора - народного депутата України чотирьох скликань О. М. Бандурки, одного 3 керівників профільної Комісії (згодом - Комітету) Верховної Ради України. Саме тоді народилися відомі закони «Про оперативно-розшукову діяльність», «Про організаційноправові основи боротьби з організованою злочинністю» та інші. У ті часи правова наука й законотворча практика йшли рука об руку. Велике значення мало те, що переважна більшість народних депутатів - членів профільних комітетів Парламенту в 1990-х - на початку 2000-х років мала досвід управлінської та правозастосовної діяльності. Дехто 3 них (Я. Ю. Кондратьєв, Е. О. Дідоренко), як і О. М. Бандурка, крім особистого наукового пошуку, спирались у своїй законотворчий роботі на здобутки потужних колективів фахівцівдослідників.

З 2005 року автору цих рядків довелося брати участь у реформуванні правоохоронних органів уже безпосередньо в столиці, працюючи в центральному апараті Міністерства внутрішніх справ України, згодом начальником Державного науководослідного інституту МВС, а в 20082011 роках - керівником департаменту 3 питань діяльності правоохоронних органів Апарату РНБО України. Довелося працювати й в Національній академії прокуратури, а останні п'ять років - в Інституті законодавства Верховної Ради України, у співпраці 3 кількома профільними парламентськими комітетами. Багато разів брав участь у діяльності загальних і спеціалізованих міжвідомчих і відомчих робочих груп, міжнародних і національних форумів. Пишу зараз про це лише для того, щоб переконати читача: проблеми рефо- 
рмування правоохоронної системи опрацьовував 3 різних рівнів і з усіх можливих боків, у тому числі в контексті удосконалення шляхів забезпечення національної безпеки, розвитку сектору безпеки України в сучасних умовах. Отже, маю підстави вважати себе одним з ветеранів реформаційних процесів.

Нині, підводячи підсумки тридцятирічних зусиль багатьох людей, спрямованих на кардинальне реформування правоохоронної системи, слід констатувати, що вони, на превеликий жаль, не призвели врештірешт до вирішального успіху. Стратегічна лінія реформ (якщо таку, озираючись назад, можна віднайти) не була чітко визначена на перспективу, не отримала належного закріплення у відповідних документах, достатньої нормативно-правової, організаційної, кадрової, фінансовоматеріальної, ідеологічної підтримки, періодично переживала коливання та навіть фактичний рух назад (хоч офіційно це ніколи не проголошувалось). У результаті, певні здобутки й досягнення (а вони, безперечно, мали місце) не були підтримані й закріплені, а переважно вже зійшли нанівець або ж перебувають на шляху до цього.

Підтвердженням справедливості такої прикрої оцінки може слугувати нинішній стан правопорядку в країні. Навряд чи хтось із неупереджених громадян України буде заперечувати очевидне: кримінальна ситуація в країні залишається напруженою, рівень злочинності $€$ високим. Нехай нікого не вводять в оману заяви керівництва Національної поліції 3 оцінкою ситуації за останні роки про «стабільну тенденцію до зменшення кількості вчиню- ваних злочинів»: автори заяв оперують даними не про «вчинювані», а лише про «обліковані» кримінальні правопорушення (а це далеко не одне й те ж, бо існує величезний масив латентних, тобто прихованих, злочинів); при визначенні реального рівня злочинності слід обов'язково враховувати зменшення, в силу всім відомих подій, чисельності населення країни (йдеться не лише про тимчасову втрату нами значних територій, а й про міграційні процеси, зокрема виїзд за кордон великої кількості осіб - передусім чоловіків - у віці, коли найбільш виявляється схильність до кримінальної активності). Отже, об'єктивних підстав до оптимістичних оцінок не вбачається.

Але справа не тільки в кількісних характеристиках злочинності; відбуваються якісні зміни в їі структурі, злочинність стає все більш агресивною, організованою, мобільною, технологічно озброєною, набуває транснаціонального розмаху. Сприятливим «фоном», живильним середовищем для поширення і відновлення злочинності $\epsilon$ майже всеохоплююча корупція. Відбувається стрімкий процес криміналізації суспільних відносин. Буяє пишним цвітом правовий нігілізм. I вже, мабуть, небезпідставною виглядає висловлена в новітній юридичній літератуpi думка про імітативний (ілюзорний) характер сучасного українського права.

Певна річ, нинішній стан речей в країні та його складові (в тому числі кримінальна ситуація) $є$ результатом впливу багатьох причин та умов суспільно-політичного, соціальноекономічного, культурного, правового, екологічного, воєнного, зовнішньополітичного тощо характеру. Вже 
минули ті часи, коли офіційно ставилася задача з викорінення злочинності взагалі, коли за їі стан питали лише або передусім з правоохоронних органів. Проте не можна впадати й в іншу крайність: у сфері забезпечення безпеки, протидії криміналу правоохоронні інституції мають свою, досить широку, «зону відповідальності». I суспільству в цілому, і окремим громадянам далеко не байдуже, чи відповідають «реформовані» правоохоронні органи тим завданням, які перед ними поставлені в сучасних умовах, чи вийшли вони на рівень «європейських стандартів» (а про ці стандарти рефреном йдеться у новоприйнятих законодавчих актах, у всіх без винятку концепціях, стратегіях, програмах тощо. Такий інтерес до цих питань тим більш виправданий, що правоохорона небагатому українському суспільству обходиться дуже недешево.

Що ж ми маємо на сьогодні? Жодна з реформ у правоохоронній сфері не доведена до бажаного кінця! Тут необхідно звернути увагу й на судову реформу, оскільки в аспекті, що нас цікавить, слід розглядати систему кримінальної юстиції в цілому. Про нинішній стан судової влади годі й говорити (достатньо оцінити принаймні рівень реалізації для українців права на доступ до правосуддя).

Багато говорили й писали про реформу міліції/поліції, її вважають найуспішнішою серед перетворень у правоохоронній системі. Варто частково погодитись: з 2015 р. зроблено чимало, момент для перетворень був обраний досить вдало, замість міліції, яка вже історично віджила своє, створювалася «нова поліція» під європейські стандарти (можна побачи- ти й використання американських стандартів). За допомогою західних партнерів залучено великі кошти, отримана вагома методична, матеріально-технічна та ідеологічна підтримка тощо. Кроки з реалізації поліцейської реформи на перших етапах характеризувалися високим динамізмом. Проте далеко не все вдалося реформаторам: після створення патрульної поліції (на це були кинуті основні ресурси) подальші перетворення уповільнилися, а потім і загальмувалися.

Ситуація склалася несприятлива для подальшої долі реформи в цілому: в межах однієї системи опинилися одночасно і співіснують якісно різні елементи - реформовані й нереформовані (вони були піддані перетворенням лише формально). Таке співіснування аж ніяк не назвеш мирним, зазначені складові поліцейської системи за визначенням перебувають в стані жорсткої боротьби (нехай зовні й не завжди помітної). За таких умов, при припиненні постійної «підживлення» з боку суспільства і держави, при втраті планомірної наступальності нове невідворотно поступається старому, тобто відбувається своєрідний реванш, про який, щоправда, офіційно не оголошують. I вже бачимо ми ознаки фактичного відродження гонитви за формальними показниками (про це свідчить і збільшення кількості застосування тортур в поліції), і оголошення 3 високих трибун надто оптимістичних оцінок результатів роботи, і спроби так чи інакше (поки що неявно, непрямими діями) забезпечити «справні цифри» щодо рівня довіри населення до поліції (бо встановили ж цей показник як головний при оцінці ефективності діяльності 
поліції). Поступова здача завойованих раніше позицій в реформаційному поступі чималою мірою зумовлена й наслідками помилок, що були припущені в процесі створення «нової поліції». Намагання дуже швидко запровадити демократичні принципи комплектування патрульної поліції під гаслом долання «бюрократичних перешкод», недостатнє вивчення особистості кандидатів мали призвели до попадання до ії лав людей, які не виправдали виказаної до них довіри (це виявлялося вже пізніше, i досить дорогою ціною). Серйозною помилкою можна вважати нав'язаний відомими всім іноземними «реформаторками» підхід, спрямований на жорстке протиставлення «нових» «старим» (на кшталт: «Ви - копи, і у вас не може бути нічого спільного 3 «ментами»). Вкупі з встановленням на тому етапі представникам патрульної поліції значно вищої, в порівнянні з оперативниками і слідчими, заробітної платні , це призводило до психологічної напруги в колективах, відтоку добре підготовлених професіоналів. Це фактично завершило процес втрати органами внутрішніх справ професійного ядра (у попередні періоди цьому сприяли масштабні, часто необгрунтовані «чистки» особового складу, нестабільність умов соціального забезпечення працівників).

Інші суб'єкти правоохоронної системи України мають наразі ще менше підстав говорити про свої досягнення в реформуванні. Вже не перший рік «лихоманить» прокуратуру. Інше слово важко підібрати, якщо уявити собі стан працівників: атестації й перепризначення на посади накочуються хвилями, вимагаючи величезних витрат часу й нер- вової енергії для чергової кампанії з складання тестів та співбесід. I це при тому, що існує сучасний за змістом Закон, положення якого отримали схвалення з боку міжнародної спільноти, в тому числі авторитетної Венеціанської комісії. Замість того, щоб реалізовувати закон, влада (i попередня, і нинішня) заходилася вносити до нього зміни, які нічим іншим, крім політичних міркувань, пояснити важко.

Дуже багато говорилося й писалося про реформування, «осучаснення» Служби безпеки України. Цього року вже здавалося, що реформування таки відбудеться, але, схоже, справа знову відкладається. Невже науковцям доведеться готувати чергове, сьоме чи десяте видання Коментаря до Закону 1992 р.?

Дивні справи відбуваються i навколо правоохоронної інституції 3 майже реліктовою назвою - податкова міліція: вже п'ятий рік її обіцяють реформувати/ліквідувати (бо нікуди не годиться, зокрема, що правоохоронний орган перебуває $\mathrm{y}$ складі органу виконавчої влади), i вже відповідний законопроект попередньо розглядався у Верховній Раді. Аж раптом, як сказала одна депутатка 3 «монобільшості», «зникла політична воля».

Справжню епопею переживає кримінально-виконавча служба: на минулорічній міжнародній науковопрактичній конференції учасники підрахували, що було вже десять офіційних документів щодо реформування системи виконання покарань, а по-справжньому вагомих результатів дотепер не досягнуто. Чи, може, до таких результатів слід віднести обладнання VIP-камер у слідчих ізоляторах? 
Характеристика стану правоохоронної системи не буде повною без згадки, поруч зі «старими», про «нових» суб'єктів: НАБУ та ДБР. Перший з них привертає до себе увагу передусім тим, що на нього покладалися великі сподівання, витрачаються 3 бюджету величезні кошти, але своєї ефективності цей орган ще не довів. ДБР - ще дуже молода інституція, працює більш активно, але остаточну оцінку давати зарано. Тривожить, що і НАБУ, і ДБР перебувають в епіцентрі політичних впливів (як внутрішніх, так і закордонних), що, безперечно, не сприяє виконанню ними визначених законом завдань.

Мабуть, доводити далі кризовий стан правопорядку в країні, реальність кримінальної загрози, незадовільний стан правоохоронної системи не варто - це цілком очевидно і майже ні у кого не викликає сумнівів. Завдання науки полягає в тому, щоб на основі неупередженого аналізу виявити і розкрити причини неуспішності багаторічних реформ (як об'єктивного, так і суб'єктивного характеру), розробити методологію перетворень, запропонувати алгоритм відповідних кроків тощо.

Висновки. Тут буде доречно звернутися до положень науки, спеціальної і, на жаль, часто-густо мало відомої серед тих, хто береться за планування та здійснення реформ. Це реформаціологія - молода наука про суспільні реформи. Використання її здобутків, вкупі з дослідженням практичного досвіду перетворень у правоохоронній сфері (як позитивного, так і негативного) переконує, що успішне реформування правоохоронних органів може здійснюватися лише комплексно й на базі системної методології. Це означає, що, наприклад, поліція має розглядатися не ізольовано, не як самостійний об'єкт реформування, а в якості складової інституційної системи. До цієї системи, поряд із самими правоохоронними органами, входять кадровий, матеріально-технічний, правовий та ідеологічний компоненти. В свою чергу, правоохоронна система входить в якості підсистеми до складу системи більш загального порядку - державно-правової. Кожний 3 правоохоронних органів $\epsilon$ органічною системою, де функціонування кожної складової залежить, так чи інакше, від інших. Ось чому не можна зупинятися в перетвореннях в межах однієї інституції.

Реформа у правоохоронній сфері - різновид суспільної реформи. Для того, щоб вона була успішною, необхідна, передусім, суспільна потреба в перетворенні. Така потреба в нашій країні, безперечно, є. Але вкрай важливо, щоб була ще політична воля до проведення реформ. Саме відсутність або слабкість такої волі були однією з причин неуспішності реформ (в таких випадках ми маємо здебільшого імітацію реформ). Реформи мають бути взаємоузгодженими, продуманими і послідовними. Усі сфери суспільного життя $\epsilon$ взаємопов'язаними, внаслідок чого зміни в одній сфері корелюють із виникаючими наслідками в іншій сфері. Якість реформ напряму залежить від чіткості уявлень їх ініціаторів і проектантів щодо моделі того чи іншого перетворення. Перспективною для використання при підготовці реформування видається запропонована вітчизняною дослідницею Л. Бойко-Бойчук версія створення інтегральної моделі реформи як керованої соціальної інновації. 
Рік тому, коли команда новообраного президента готувалася офіційно отримати повноваження й оголошувала про свої найближчі наміри, мені дуже сподобалася одна думка: «Провести аудит держави». Йшлося навіть про перші сто днів. Не будемо зараз звертати увагу на явно нереальний термін, віднесемо це на цілком зрозумілий максималізм молодої команди. Варто підкреслити інше - «аудит» включав не тільки перепис населення (справа, дійсно, непроста, потребує серйозної підготовки), а і складову правоохоронного характеру. Декому тоді це, мабуть, не сподобалось, але переважна більшість людей сприйняла схвально. На жаль, вагомих результатів до сих пір немає. Багато часу упущено, і нинішній владі наразі уже політично не зовсім вигідно розпочинати велику, копітку роботу, щоб встановити i оголосити народу, «в якому стані держава» і «що в державі є» (уже не всі негаразди і нестачі можна покласти на попередників). Але якщо влада, яка отримала на президентських і парламентських виборах безпрецедентну підтримку, і на яку й зараз покладають надію дуже багато українців, буде керуватися не суто політичними міркуваннями, а бажанням по-справжньому змінити життя народу на краще, «аудит держави» (в тому числі сектору безпеки, правоохоронної системи) треба обов'язково провести. I зробити це доцільно незабаром після закінчення коронавірусної пандеміi, яка стала вкрай серйозним випробуванням спроможності держави діяти в особливих умовах. «Вікно можливостей» для збереження і зміцнення української демократичної державності , оздоровлення суспільства, прогресу країни ще відкрите, треба діяти.

o. Yarmysh, Doctor of Law, Professor, Corresponding Member of National Academy of Legal Sciences of Ukraine, Honored Lawyer of Ukraine

ORCID: 0000-0002-4811-4520

\section{Transformations of the law enforcement system of independent Ukraine: why haven't they brought success so far? (reflections of the veteran participant in the reformist effort)}

In the article from the point of view of scientific validity and practical experience the reforms of law enforcement system of recent years are considered, the achievements and shortcomings on the way of reforming the police, prosecutor's office, SBU, criminal enforcement service, etc. are assessed.

Summing up thirty years of efforts of many people aimed at cardinal reform of the law enforcement system, it should be noted that, unfortunately, they have not led to success. The strategic line of reforms was not clearly defined for the future, was not properly fixed in the relevant documents, was not provided with sufficient regulatory, organizational, human resources, financial and material, ideological support, was periodically experiencing hesitation and even actual movement backwards. 
The author suggests that the said objects of reform should not be viewed in isolation, but as components of the institutional system from the standpoint of efficiency of transformations of the entire state and legal structure. Therefore, it is impossible to stop within the framework of reforming one institution.

For example, the police should not be regarded in isolation, not as an independent object of reform, but as a component of the institutional system. This system, along with the law enforcement agencies themselves, includes personnel, material and technical, legal and ideological components. In its turn, the law enforcement system is included as a subsystem of a more general system - the state and legal system. Each of the law enforcement agencies is an organic system, where the functioning of each component depends, one way or another, on the others. That is why one cannot stop at transformations within one institution.

Keywords: the enforcement system; police; reform; integral reform model. 